\title{
Contents of Erythorbic Acid in the Tissues of Guinea Pigs Intraperitoneally Administered Erythorbic Acid
}

\author{
Emiko Suzuki, ${ }^{1}$ Tadao Kurata ${ }^{2}$ and Nobuhiko Arakawa ${ }^{3}$ \\ ${ }^{1}$ Department of Human Biological Studies, \\ ${ }^{2}$ Institute of Environmental Science for Human Life and \\ ${ }^{3}$ Department of Nutrition and Food Science, Ochanomizu University, \\ Bunkyo-ku, Tokyo 112-8610, Japan
}

(Received April 23, 1998)

\begin{abstract}
Summary The contents of ascorbic acid (AsA) and erythorbic acid (ErA) in the tissues of guinea pigs intraperitoneally injected with AsA and/or ErA were determined to learn the difference in their retention in the tissues. After $10 \mathrm{~d}$ of AsA depletion, the guinea pigs were intraperitoneally injected with $5 \mathrm{mg}$ of AsA, or $5 \mathrm{mg}$ of ErA, or $5 \mathrm{mg}$ of each. At day 5 of repletion, the guinea pigs were killed and liver, adrenal glands, spleen, and kidneys were removed. AsA and ErA in these tissues were measured by using HPLC. The contents of AsA in the tissues of only the AsA-injected guinea pigs were similar to those of the AsA-+ErAinjected guinea pigs. The contents of ErA in the tissues of the ErA-injected guinea pigs were higher than those of the AsA- + ErA-injected guinea pigs, but apparently lower than the contents of AsA in the AsA-injected guinea pigs. ErA was scarcely retained in the tissues of guinea pigs.
\end{abstract}

Key Words erythorbic acid, ascorbic acid, guinea pig

Erythorbic acid (ErA), which is referred to as D-isoascorbic acid or D-araboascorbic acid, is widely used as an antioxidant in various processed foods. In our previous paper, the contents of ascorbic acid (AsA) in the tissues of guinea pigs administered $5 \mathrm{mg}$ of AsA with $1 \mathrm{mg}$ or $5 \mathrm{mg}$ of ErA were similar to those of the guinea pigs administered only $5 \mathrm{mg}$ of AsA. On the other hand, the tissue contents of AsA in the guinea pigs administered $5 \mathrm{mg}$ of AsA together with $100 \mathrm{mg}$ of ErA decreased in comparison with those of the $5 \mathrm{mg}$ AsA-administered guinea pigs (1). Furthermore, the tissue contents of ErA in the guinea pigs administered $20 \mathrm{mg}$ of ErA tended to be higher than those of the guinea pigs administered $20 \mathrm{mg}$ of ErA with $5 \mathrm{mg}$ of AsA $(1,2)$. Hidiroglou et al reported that the tissue AsA contents in guinea pigs administered $1 \mathrm{mg}$ of AsA and $20 \mathrm{mg}$ or $100 \mathrm{mg}$ of ErA were lower than those of guinea pigs administered only $1 \mathrm{mg}$ of AsA (3).

In spite of several reports on the AsA and ErA contents in the tissues of orally administered guinea pigs, only a little information is available on the other means 
of administration, such as intraperitoneal or intravenous administration. In the intraperitoneal and intravenous injections, the difference in the tissue contents of AsA and ErA is not attributed to the difference in the absorption amount in the small intestine. Moreover, a few reports described the uptake of AsA and ErA in the tissues in vitro or in situ. For instance, we reported that the absorption amount of AsA in guinea pig small intestine was higher than that of ErA, and that AsA inhibited ErA absorption and vice versa (4).

In this study, the AsA and ErA contents in the tissues of guinea pigs intraperitoneally injected with AsA and/or ErA were determined so that the difference in their retention in the tissues could be learned. Furthermore, the enzyme activities, which are known to be influenced by the tissue's vitamin $\mathrm{C}$ level, were measured to assess the vitamin $\mathrm{C}$ status of the animals.

\section{MATERIALS AND METHODS}

Animals and diet. Male Hartley guinea pigs with initial body weights of about $230 \mathrm{~g}$ were individually placed in wire cages and fed an AsA-deficient diet (I); water was freely supplied.

Experimental design. After $10 \mathrm{~d}$ of AsA depletion, the guinea pigs were divided into 3 groups and intraperitoneally injected with $5 \mathrm{mg}$ of AsA (group A, 4 animals), $5 \mathrm{mg}$ of ErA (group B, 5 animals) and $5 \mathrm{mg}$ AsA together with $5 \mathrm{mg}$ ErA (group C, 5 animals). AsA and/or ErA were dissolved in $0.9 \% \mathrm{NaCl}$ solution immediately before use. At day 5 of repletion, guinea pigs were killed; liver, adrenal glands, spleen, and kidneys were removed, and blood was collected from the abdominal aorta.

Enzyme assays. The activities of liver aniline hydroxylase and of liver acid phosphatase and the contents of liver cytochrome P-450 were measured by the methods of Imai et al (5), Desai (6), and Omura and Sato (7), respectively. The activity of serum alkaline phosphatase was assayed by using the Alkaline Phospha B-Test (Wako Pure Chemical, Osaka, Japan).

Protein was determined by the method of Lowry et al (8), using bovine serum albumin as standard.

Determination of AsA and ErA contents. The contents of AsA and ErA in the tissues were simultaneously determined by using HPLC (l).

Statistical analysis. Data were analyzed by using ANOVA and by Duncan's new multiple range test (9).

This study was approved by the committee for animal experiments of the School of Human Life and Environmental Science, Ochanomizu University, and the animals were maintained in accordance with the school's guidelines for the care and use of laboratory animals. 


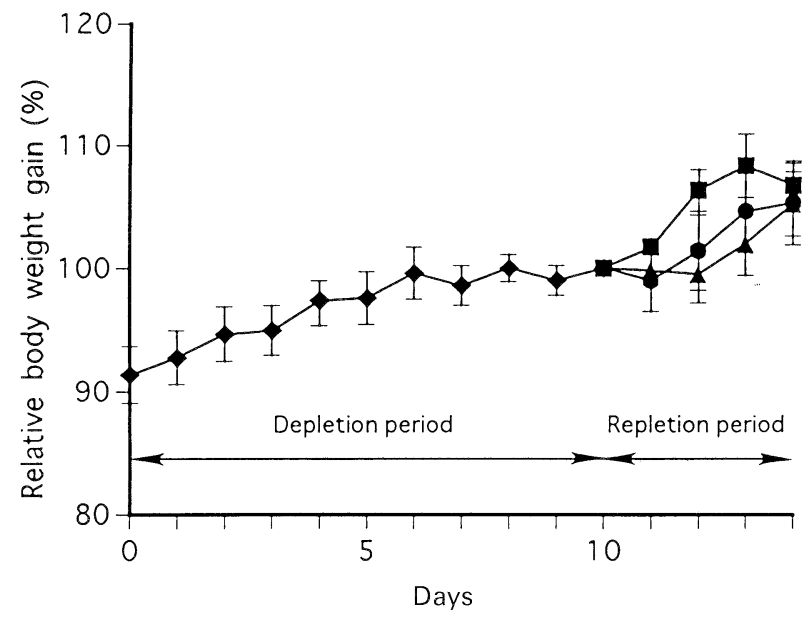

Fig. 1. Body weight changes of guinea pigs during depletion and repletion periods. Symbols represent means and vertical bars represent SE. [: $5 \mathrm{mg}$ AsA-injected guinea pigs, ๑: $5 \mathrm{mg}$ ErA-injected guinea pigs, $\boldsymbol{\Delta}$ : $5 \mathrm{mg}$ AsA- and $5 \mathrm{mg}$ ErAinjected guinea pigs.

\section{RESULTS AND DISCUSSION}

Figure 1 shows the guinea pig body weight changes during depletion and repletion periods. In the depletion period, no body weight loss was observed; however, the body weight gains of animals after starting repletion seemed to be higher in comparison with those observed in the depletion period, and no significant difference was noted in body weight gains among the three groups: AsA-injected, ErA-injected, and AsA-+ErA-injected. Because of these results, it was thought that the injection of ErA did not depress guinea pig body weight gain.

The contents of AsA in the liver, adrenal glands, spleen, and kidneys of the only AsA-injected guinea pigs were similar to those of the AsA- + ErA-injected guinea pigs and were higher than those of the ErA-injected guinea pigs (Table 1). The contents of ErA in the tissues of the ErA-injected guinea pigs were apparently higher than those of the AsA-+ErA-injected guinea pigs; however, they were apparently lower than those of AsA in the AsA-injected animals.

In this study, AsA and/or ErA were injected in the 10-d-AsA-deficient guinea pigs. The liver acid phosphatase and serum alkaline phosphatase activities and the contents of liver cytochrome P-450 in the 10-d-AsA-deficient guinea pigs were similar to those of the $5 \mathrm{mg}$ AsA-administered guinea pigs (10). Based on these observations, the 10-d-AsA-deficient guinea pigs and the mechanisms of tissue absorption and retention of AsA were considered to be in the normal state. Thus the results described in this paper were those of the animals that were in a physiologically normal state. Because AsA was hardly contained in the tissues of 
Table 1. Contents of AsA and ErA in liver, adrenal glands, kidneys, and spleen of guinea pigs intraperitoneally injected with AsA and/or ErA at day 5 of repletion.

\begin{tabular}{|c|c|c|c|c|}
\hline \multirow{2}{*}{ Group } & \multicolumn{2}{|c|}{ Liver } & \multicolumn{2}{|c|}{ Adrenal glands } \\
\hline & AsA & ErA & AsA & ErA \\
\hline $\mathrm{A}$ & $8.43 \pm 2.74^{* a}$ & - & $47.6 \pm 3.4^{\mathrm{a}}$ & - \\
\hline B & $\operatorname{tr}$ & $0.62 \pm 0.42^{\mathrm{a}}$ & $1.3 \pm 0.1^{\mathrm{b}}$ & $13.6 \pm 3.5^{\mathrm{a}}$ \\
\hline $\mathrm{C}$ & $7.81 \pm 0.98^{\mathrm{a}}$ & $0.31 \pm 0.11^{\mathrm{a}}$ & $42.2 \pm 6.1^{\mathrm{a}}$ & $4.3 \pm 0.5^{\mathrm{b}}$ \\
\hline \multirow{2}{*}{ Group } & \multicolumn{2}{|c|}{ Spleen } & \multicolumn{2}{|c|}{ Kidneys } \\
\hline & AsA & ErA & AsA & ErA \\
\hline A & $19.4 \pm 4.3^{\mathrm{a}}$ & - & $4.31 \pm 0.58^{\mathrm{a}}$ & - \\
\hline $\mathrm{B}$ & $0.4 \pm 0.1^{\mathrm{b}}$ & $1.5 \pm 0.8^{\mathrm{a}}$ & $0.04 \pm 0.04^{\mathrm{b}}$ & $0.27 \pm 0.11^{\mathrm{a}}$ \\
\hline $\mathrm{C}$ & $21.8 \pm 2.9^{\mathrm{a}}$ & $0.6 \pm 0.2^{\mathrm{a}}$ & $3.64 \pm 0.67^{\mathrm{a}}$ & $0.10 \pm 0.03^{\mathrm{a}}$ \\
\hline
\end{tabular}

A: $5 \mathrm{mg}$ AsA intraperitoneally injected. B: $5 \mathrm{mg}$ ErA intraperitoneally injected. C: $5 \mathrm{mg}$ AsA and $5 \mathrm{mg}$ ErA intraperitoneally injected.

*Values (mg/100 g of tissues) are means \pm SE, $n=4-5$.

Means within the same column not sharing a common superscript letter are significantly different $(p<0.05)$.

tr: trace.

10-d-AsA-deficient guinea pigs, the amounts of AsA and ErA retained in the tissues of guinea pigs injected with AsA and/or ErA were regarded to be derived from the AsA and ErA intraperitoneally injected during the repletion period. These results showed a tendency similar to the results observed in the oral ErA administration test (1). The amount of AsA absorbed and retained in the tissues was higher than those of ErA, and ErA was hardly retained. The mechanism of retention of AsA and ErA in the tissues might be different, but this is still not known; therefore further study is necessary. The ErA contents in the tissues of guinea pigs injected with AsA and ErA were lower compared with those of the guinea pigs injected with only ErA, and this phenomenon might be due to the inhibitory effect of AsA against the absorption of ErA. On the contrary, no apparent decrease was found of AsA tissue content of guinea pigs injected with AsA and ErA. Furthermore, the uptake of AsA in polygonal astrocytes of rat incubated in media containing $5 \mu \mathrm{M}$ of AsA and $10 \mu \mathrm{M}$ of ErA was similar to that in media containing only AsA (11). The results showed that the inhibitory effect of ErA against AsA absorption into the tissues is much weaker compared with that of AsA for ErA absorption. These observations agreed with our previous experimental results obtained in a perfusion test carried out by using the guinea pig small intestine (4). These results suggested that ErA did not reduce the bioavailability of AsA when the amount of AsA administered was equal to ErA. 
Table 2. Activities of aniline hydroxylase, acid phosphatase, and serum alkaline phosphatase, and contents of cytochrome P-450 of guinea pigs intraperitoneally injected with AsA and/or ErA at day 5 of repletion.

\begin{tabular}{ccc}
\hline Group & $\begin{array}{c}\text { Aniline hydroxylase } \\
\text { (nmol } p \text {-aminophenol } \\
\text { formed/min/mg of protein) }\end{array}$ & $\begin{array}{c}\text { Acid phosphatase } \\
\text { (nmol } p \text {-nitrophenol } \\
\text { liberated } / \text { min } / \mathrm{mg} \text { of protein) }\end{array}$ \\
\hline A & $0.268 \pm 0.059^{* *}$ & $51.3 \pm 3.6$ \\
B & $0.265 \pm 0.045$ & $51.4 \pm 1.6$ \\
C & $0.239 \pm 0.015$ & $47.9 \pm 1.9$ \\
D* & $0.109 \pm 0.015$ & $58.9 \pm 3.2$ \\
\hline & & \\
Group & Serum alkaline phosphatase & Cytochrome P-450 \\
& (mmol $p$-nitrophenol & (nmol/mg of protein) \\
A & liberated/h/L) & $0.76 \pm 0.09$ \\
B & $6.89 \pm 1.01$ & $0.76 \pm 0.12$ \\
C & $5.07 \pm 0.63$ & $0.69 \pm 0.11$ \\
D* & $7.99 \pm 1.26$ & $0.50 \pm 0.05$ \\
\hline
\end{tabular}

A-C: same as in Table 1 legend.

* D: 16-d-AsA-deficient guinea pigs (10).

$* *$ Values are means \pm SE, $n=4-5$.

No difference was evident in the activities of aniline hydroxylase, acid phosphatase, and serum alkaline phosphatase, and in the content of cytochrome P-450 among the three groups injected with AsA, ErA, and AsA + ErA (Table 2). It was known that the activities of aniline hydroxylase and serum alkaline phosphatase and the contents of cytochrome P-450 in AsA-deficient guinea pigs were lower than those in normal animals and that the activity of acid phosphatase was higher than in normal animals (10). Mahmoodian et al reported that the activity of serum alkaline phosphatase, which is thought to be released from tissues into the blood stream, decreased and the concentration of alkaline phosphatase mRNA in bone was reduced in scorbutic guinea pigs (12). It might be suggested that AsA could regulate the expression of alkaline phosphatase. Leveille and Schwartz reported that the activity of acid phosphatase in the adrenal glands and in the cartilage of guinea pigs on low AsA level was higher than that of guinea pigs on high AsA level (13). Moreover, Hoehn and Kanfer showed that the activity of acid phosphatase in the liver of guinea pigs administered a low level of AsA was higher than that of guinea pigs administered a high level (14). These results suggested that the acid phosphatase activity might be influenced by AsA-deficiency in guinea pigs. The activities of aniline hydroxylase and serum alkaline phosphatase and the content of cytochrome P-450 obtained after a 5-d repletion period were higher than those in the 16-d-AsA-deficient guinea pigs, and the activity of acid phosphatase in this 
study was lower. These observations showed that guinea pigs in all three groups were not in an AsA-deficient state. We observed that the activity of ErA as a cofactor for dopamine $\beta$-hydroxylase reaction was the same as that of AsA when the ErA concentration in the enzyme reaction mixture was equal to the AsA concentration (15). Furthermore, the enzyme activities and the cytochrome P-450 content in the ErA-injected guinea pigs were similar to those of AsA-injected guinea pigs, although the ErA contents of the tissues were very low compared with the AsA contents of AsA-injected guinea pigs. The findings described above suggested that the tissue contents of ErA might be similar in levels to the tissue contents of AsA just after ErA injection. The ErA contents in tissues measured $24 \mathrm{~h}$ after the last injection were low, suggesting that ErA was hardly retained in the guinea pig tissues.

Our results in this study suggested that ErA was hardly retained in the guinea pig tissues compared with AsA, and that AsA might inhibit the absorption of ErA into the tissues.

\section{REFERENCES}

1) Suzuki E, Kurata T, Sanceda N, Arakawa N. 1986. Effect of graded doses of erythorbic acid on ascorbic acid content of tissues of guinea pigs. J Nutr Sci Vitaminol 32: 335-342.

2) Suzuki E, Kurata T, Koda M, Arakawa N. 1987. Erythorbic acid content in tissues of guinea pigs administered erythorbic acid. J Nutr Sci Vitaminol 33: 169-175.

3) Hidiroglou N, Madere R, L'Abbe MR. 1997. Influence of oral dosing with D-isoascorbic acid on L-ascorbic acid content in guinea pig tissues. $J$ Nutr Biochem 8: 13-18.

4) Suzuki E, Kurata T, Arakawa N. 1991. Comparison of absorption of erythorbic acid and ascorbic acid in guinea pig small intestine. J Nutr Sci Vitaminol 37: 453-459.

5) Imai Y, Ito A, Sato R. 1966. Evidence for biochemically different types of vesicles in the hepatic microsomal fraction. $J$ Biochem 60: 417-428.

6) Desai ID. 1969. Regulation of lysosomal enzymes. I. Adaptive changes in enzyme activities during starvation and refeeding. Can J Biochem 47: 785-790.

7) Omura T, Sato R. 1964. The carbon monoxide-binding pigment of liver microsomes. $J$ Biol Chem 239: 2370-2378.

8) Lowry OH, Rosebrough NJ, Farr AL, Randall RJ. 1951. Protein measurement with the Folin phenol reagent. $J$ Biol Chem 193: 265-275.

9) Duncan DB. 1957. Multiple range tests for correlated and heteroscedastic means. Biometrics 13: 164-176.

10) Suzuki E, Kurata T, Arakawa N. 1989. Effect of erythorbic acid administration on activities of drug metabolic enzyme and phosphatases in guinea pigs administered an adequate amount of ascorbic acid. J Nutr Sci Vitaminol 35: 123-131.

11) Wilson JX. 1989. Ascorbic acid uptake by a high-affinity sodium-dependent mechanism in cultured rat astrocytes. $J$ Neurochem 53: 1064-1071.

12) Mahmoodian F, Gosiewska A, Peterkofsky B. 1996. Regulation and properties of bone alkaline phosphatase during vitamin $\mathrm{C}$ deficiency in guinea pigs. Arch Biochem Biophys 336: 86-96.

13) Leveille C, Schwartz E. 1982. Effect of ascorbate on lysosomal enzyme activities in guinea pig cartlage and adrenals. Int J Vit Nutr Res 52: 436-441. 
14) Hoehn S, Kanfer J. 1980. Effects of chronic ascorbic acid deficiency on guinea pig lysosomal hydrolase activities. J Nutr 110: 2085-2094.

15) Suzuki E, Kurata T, Shibata M, Mori M, Arakawa N. 1997. Activities of D- and L-xyloascorbic acid and D- and L-araboascorbic acid as a cofactor for dopamine $\beta$-hydroxylase reaction. J Nutr Sci Vitaminol 43: 491-496. 